\section{(C) OPEN ACCESS}

\title{
Alcohol and other drug use among Belgian workers and job-related consequences
}

\author{
Marie-Claire Lambrechts, ${ }^{\oplus 1,2}$ Lieve Vandersmissen, ${ }^{3}$ Lode Godderis ${ }^{1,3}$
}

\begin{abstract}
- Additional material is published online only. To view please visit the journal online (http://dx.doi.org/10.1136/ oemed-2019-105690).
\end{abstract}

${ }^{1}$ Centre for Environment and Health, KU Leuven, Leuven, Belgium

${ }^{2} V A D$, the Flemish centre of expertise on alcohol and other drugs, Brussels, Belgium

${ }^{3}$ Knowledge, Information and Research, IDEWE vzW, Leuven, Belgium

\section{Correspondence to}

Mrs Marie-Claire Lambrechts, Environment and Health, KU Leuven, University of Leuven, B 3000 Leuven, Belgium; marieclaire.lambrechts@ kuleuven.be

Received 1 January 2019 Revised 12 June 2019

Accepted 30 June 2019

\section{Check for updates}

(c) Author(s) (or their employer(s)) 2019. Re-use permitted under CC BY-NC. No commercial re-use. See rights and permissions. Published by BMJ.

To cite: Lambrechts $\mathrm{M}-\mathrm{C}$, Vandersmissen L, Godderis L. Occup Environ Med 2019:76:652-659.

\begin{abstract}
Objectives This study aimed to obtain prevalence data on use of alcohol and other drugs (AOD) among Belgian workers, and to explore the associations between selfreported AOD use and job-related effects as experienced by workers, and the level of workers' well-being, respectively.
\end{abstract}

Methods In this cross-sectional study (2016), 5367 workers filled out a questionnaire including validated instruments such as the Alcohol Use Disorders Identification Test-Consumption (AUDIT-C). Job-related effects were defined as: being late at work, absenteeism, loss of productivity, injuries, conflicts with co-workers and sanctions by employers. Descriptive and multiple logistic regression analyses were performed.

Results Based on AUDIT-C, $39.1 \%$ of last year drinkers had an indication of problem drinking. The odds of experienced job-related effects was $3.6(\mathrm{Cl} 2.86$ to 4.60$)$ times larger than the odds among workers without this indication. This ratio decreased to $3.2(\mathrm{Cl} 2.52$ to 4.11$)$, controlling for language, gender, family context, level of education and sector. Respondents who used illicit drugs more frequently (>once a month) also had an increased risk for experienced job-related effects (OR 5.8; Cl 2.87 to 11.84). Having a low level of well-being increased the risk for job-related effects due to psychoactive medication (OR 2.3, Cl 1.10 to 4.91).

Discussion In this study, self-reported AOD use was associated with short-term job-related effects. This suggests that an AOD policy in different sectors is needed with respect for the organisational culture. Its focus should lie on prevention and early detection of AOD problems, and on the mental health of workers. Attention is required for the non-medical use of prescription drugs.

\section{INTRODUCTION}

The impact of alcohol and other drug (AOD) use is a major public health concern but depends largely on the type of drug used. Worldwide, alcohol is the most prevalently used drug. ${ }^{1}$ The highest consumption levels ( $\geq 101$ of pure alcohol per year) are found in the European Union (EU) and among male drinkers. ${ }^{1}$ Alcohol consumption plays a role in more than 200 diseases and injury conditions. ${ }^{2}$ Worldwide more than 3 million deaths per year are associated with alcohol use, $28.7 \%$ of which are due to injuries. ${ }^{2}$ Cannabis is the most commonly used illegal drug. ${ }^{3}$ The average per capita consumption of benzodiazepines, predominantly by female users, is much higher in the EU than in any other region in the world, especially in Belgium. ${ }^{4}$ Finally,

\section{Key messages}

What is already known about this subject?

- Preliminary studies suggest that alcohol and other drug (AOD) use of workers may have negative consequences, mostly defined as long-term health and safety problems. AOD use might also be influenced by work-related risk factors.

\section{What are the new findings?}

- Respondents with an indication of problem use had an increased risk for a range of selfreported job-related effects. Regarding alcohol use, the Alcohol Use Disorders Identification Test-Consumption seems to be a good indicator.

- Having a high level of well-being at work decreased this risk although only in case of jobrelated effects due to psychoactive medication.

\section{How might this impact on policy or clinical practice in the foreseeable future? \\ - Companies should focus on short-term effects of job-related AOD use. An integrated AOD policy is a facilitating factor in this matter.}

non-medical use of prescription drugs (NMPD), including opioids, depressants and amphetamines is becoming a major issue around the world. ${ }^{5}$ NMPD refers to the self-treatment of a medical condition using medication without a prescriber's authorisation as well as use to achieve euphoric states. ${ }^{5}$

AOD use by workers is a private matter. However, it is a different story when it comes to work-related use: AOD use during the hours (immediately) before work, at work, on 'specific occasions' at work, and during travel to and from work. ${ }^{6}$ Even a limited and/or occasional amount of AOD use, both in the personal sphere and at the workplace, might have a negative impact on the workers themselves and on their colleagues. Excessive job-related consumption of AOD may lead to higher levels of sick leave, (short-term) absenteeism, ${ }^{7-9}$ and reduced performance and productivity. ${ }^{7}$ Moreover, the work environment is also faced with the consequences of AOD use on safety. ${ }^{6710-12}$

Workers can use AOD for many reasons, for pleasure or to cope with medical problems. ${ }^{13}$ AOD use might also be influenced by work-related risk factors: (1) Workplace culture (eg, physical availability of alcohol, drinking norms). (2) Alienation. (3) Working conditions (eg, high workloads, stress). (4) Policy enforcement (eg, role of 
supervisors). ${ }^{14}$ Especially perceived permissive drinking norms (ie, drinking behaviour influenced by the interpretation of drinking norms expressed by co-workers), ${ }^{15}$ working conditions and structural factors (eg, occupational status, education levels) were associated with risky alcohol use, rather than individual factors. ${ }^{10} 14$ Further, risky AOD use is associated with impaired well-being. ${ }^{16}$ A recent study (2018) indicated that risky alcohol use of Norwegian workers was associated with significantly higher levels of psychological distress and lower job satisfaction compared with workers who drank less. ${ }^{17}$ Finally, the workplace is a setting in which a combination of prevention and screening for harmful AOD use is feasible. ${ }^{18-21}$ In addition, having a job might be a motivating factor to tackle AOD problems and to avoid relapse. $^{22}$

To date, only a few studies have examined both the patterns of AOD use among workers and associated job consequences, in particular in the short term. Therefore, in addition to obtaining prevalence data on the use of AOD among Belgian workers, we aim to give an indication of experienced job-related effects of self-reported AOD use of workers. The third objective is to report on the relation between well-being and self-reported AOD use of workers.

\section{METHODS}

Design

Between October 2015 and March 2016, Belgian workers (Dutch-speaking or French-speaking) completed self-reported questionnaires and dropped them in a sealed box, while they were waiting for their periodical health examination by occupational physicians at several locations of two Occupational Health Services. The locations were geographically spread all over the country, in order to obtain a representative sample of the Belgian working population.

\section{Measures}

We used the Alcohol Use Disorders Identification Test-Consumption (AUDIT-C) to measure prevalence of alcohol consumption. This AUDIT-C screening questionnaire is the short version (3 questions) of the 10-questions AUDIT instrument. ${ }^{2324}$ AUDIT-C measures the frequency (Likert Scale from 'never' to 'four or more times a week') of alcohol consumption, the quantity of what respondents drink on a typical day and binge drinking. AUDIT-C thus focuses on consumption patterns of alcohol. To make sure that respondents would interpret 'a standard drink' correctly, we added both a description and an illustration. The AUDIT-C Score identifies at-risk drinkers who are not necessarily alcohol-dependent ${ }^{23}$ (online supplementary appendix 1 ).

To measure the prevalence of illicit drugs and NMPD, we used single-screening questions related to how frequently workers had used cannabis, other illegal drugs or prescription medication for non-medical reasons. A single-screening question is considered to be an accurate alternative for longer screening tests such as the 10-item Drug Abuse Screening Test. ${ }^{25}$ For analyses, we recoded the use of illicit drugs in occasional users ('never' and 'monthly or less') and more frequent users (' 2 to 4 times a month', ' 2 to 3 times a week' and 'four times or more a week'). Further, we measured the use of hypnotics, tranquillisers and antidepressants using a five-point Likert Scale (from 'never', 'monthly or less', 'two or four times a month', 'two to three times a week' to 'four or more times a week'). For analyses, we recoded the data in users and non-users. The same recoding was performed for NMPD. We defined drinking at the workplace as drinking during work with permission from the employer (eg, at receptions).

Questions concerning well-being at work (ie, job satisfaction, appreciation from supervisor, lack of job variety, time pressure) were derived from the burn-out study among medical doctors and nurses in Belgian hospitals. ${ }^{26}$ The questionnaire in this study was adapted from the Job-Demands Resources (JD-R) model. The JD-R model is a well-known occupational stress model focusing on negative (eg, time pressure) and positive (eg, appreciation from supervisor) work-related antecedents of a worker's well-being. ${ }^{27}$ We used five-point Likert Scales (totally disagree to totally agree).

Based on the Health and Work Performance Questionnaire from WHO, we defined short-term job-related effects of AOD as follows: being late at work, absenteeism, loss of productivity, workplace injuries and traffic incidents to or from work, conflicts with co-workers and sanctions by employers. ${ }^{28} \mathrm{We}$ asked workers literally whether they attributed the job-related effects they had experienced to their own AOD use. To avoid non-response because of the sensible character of AOD use, the same questions were used to measure workers' perception of job-related effects among their colleagues. Given the underestimation of self-reported AOD use in many studies, we used these extra questions to give us an additional idea of the effects in reality.

\section{Statistical analysis}

Descriptive statistics were calculated for: (1) Self-reported AOD use overall and distributions by sociodemographic and organisational variables and self-reported AOD use. (2) Experienced job-related effects overall (for alcohol, cannabis and other illicit drugs, and psychoactive medication, respectively) (dependent variables) and self-reported AOD use (independent variables). (3) Well-being (independent variable) and self-reported AOD use.

We used Pearson's $\chi^{2}$ test for statistically significant differences between Dutch-speaking and French-speaking workers; male and female gender; $\leq 35$ years and $>35$ years; higher and lower education levels; workers living alone or living with others; small or large companies; and the employment sectors. Further, we conducted analysis based on the AUDIT-C Score. An indication of problem drinking, based on the AUDIT-C Score, assumes a certain amount of alcohol consumption. Therefore, we excluded the abstainers, defined as those workers who had never consumed alcohol or had not in the 12 months prior to the survey. Univariate logistic regression analyses were performed to explore the associations between self-reported (problematic) AOD consumption and experienced job-related effects, and the degree of well-being, respectively. Multiple logistic regression was performed to investigate the relation between self-reported (problematic) AOD use (independent variable) and experienced job-related effects (dependent variable), and the degree of wellbeing, respectively (dependent variable), adjusted for language, gender, education level, family context and sector. We conducted statistical analysis with SPSS V.19.0 for Macintosh. Statistical significance level was set at 5\% value.

\section{RESULTS}

\section{Sample}

We invited 5709 workers to participate in our study, resulting in data from 5367 participants available for analysis (response rate: $94 \% ; 265$ blanco +77 only sociodemographic variables). Table 1 presents the sociodemographic characteristics and the 


\begin{tabular}{|c|c|}
\hline Sample characteristics $(n=5367)$ & $\%$ (valid percentage) \\
\hline \multicolumn{2}{|l|}{ Language } \\
\hline Dutch-speaking & 80.9 \\
\hline French-speaking & 19.1 \\
\hline \multicolumn{2}{|l|}{ Gender } \\
\hline Male & 44.8 \\
\hline Female & 55.2 \\
\hline \multicolumn{2}{|l|}{ Age, years } \\
\hline$<25$ & 9.6 \\
\hline $25-35$ & 29.5 \\
\hline $36-45$ & 24.3 \\
\hline $46-55$ & 24.5 \\
\hline$>55$ & 12.1 \\
\hline \multicolumn{2}{|l|}{ Educational level } \\
\hline Primary & 8.4 \\
\hline Secondary & 39.3 \\
\hline University college & 35.8 \\
\hline University & 16.5 \\
\hline \multicolumn{2}{|l|}{ Family context } \\
\hline Living alone & 10.8 \\
\hline Living with others & 89.2 \\
\hline With partner & 26.7 \\
\hline With partner and children & 45.9 \\
\hline With children & 7.5 \\
\hline With parents & 9.1 \\
\hline \multicolumn{2}{|l|}{ Seniority, years } \\
\hline$<2$ & 22.0 \\
\hline $2-10$ & 39.9 \\
\hline$>10$ & 38.1 \\
\hline \multicolumn{2}{|l|}{ Number of company workers } \\
\hline$<50$ & 36.5 \\
\hline $50-500$ & 35.5 \\
\hline$>500$ & 27.9 \\
\hline \multicolumn{2}{|l|}{ Employment sector } \\
\hline Construction & 7.1 \\
\hline Services & 12.1 \\
\hline Healthcare & 22.7 \\
\hline Distributive trade & 6.4 \\
\hline Accommodation and food service & 3.3 \\
\hline Manufacturing & 7.1 \\
\hline Education & 10.3 \\
\hline Government & 11.4 \\
\hline Transport and storage & 4.8 \\
\hline Other & 14.9 \\
\hline
\end{tabular}

employment sector of the respondents. Our sample is similar to the working population in Belgium regarding gender, age and educational level, ${ }^{29}$ taking into account that more Dutchspeaking than French-speaking respondents were included in our sample, and more Dutch-speaking respondents worked in a larger company $(>500)$.

\section{Prevalence of AOD use}

During the past 12 months prior to the study, $83.1 \%$ of all workers $(\mathrm{n}=5367)$ had drunk alcohol at least once. Dutchspeaking, male and younger ( $\leq 35$ years) respondents, workers in the construction industry, and workers with a higher educational level drank significantly more (table 2). Of last-year drinkers $(\mathrm{n}=4197), 37.1 \%$ had consumed alcohol at least two to three times a week; $24 \%$ had an average daily consumption of three to four standard units on the days they drank, which was significantly higher for younger ( $\leq 35$ years), male and less educated workers, and within manufacturing, accommodation and food services and the construction industry (table 3). Of last-year drinkers, $22.7 \%$ and $8.6 \%$ had exhibited binge drinking at least once a month and once a week, respectively.

Based on AUDIT-C, 39.1\% of last-year drinkers had an indication of problematic drinking (table 3). Especially workers who were living alone had a higher risk (OR 1.75, CI 1.39 to 2.20, $\mathrm{p}<0.001$ ). Even though workers with a higher education level in our study drank more frequently and had a higher AUDIT-C Score, we noticed a higher prevalence of excessive drinking and alcohol-related problems in workers with lower educational levels. To a lesser extent this was also the case for male workers (OR 1.6, CI 1.40 to $1.90, \mathrm{p}<0.001$ ), and for workers $\leq 35$ years (OR 1.27, CI 1.14 to $1.54, \mathrm{p}=0.007$ ).

Cannabis $(7.4 \%)$ was the most frequently used illicit drug and significantly involved more male workers $(11.9 \%$ vs $3.9 \%$, $\mathrm{p}<0.001)$ and workers under the age of 36 years $(14.4 \%$ vs $2.8 \% ; \mathrm{p}<0.001)$. Other illicit drugs $(2.8 \%)$ were cocaine $(1.4 \%)$, XTC (ecstasy) (1.1\%) and speed (0.6\%). Unlike alcohol, respondents with a lower level of education used more illicit drugs (table 2). Of all respondents, 3.4\% (cannabis) and 0.7\% (other illicit drugs) exhibited more frequent illicit drug use (ie, more than once a month within the last year).

Especially male (OR 3.7, CI 2.46 to $5.61, \mathrm{p}<0.001$ ) and younger workers ( $\leq 35$ years) (OR 5.5, CI 3.57 to 8.40 , $\mathrm{p}<0.001)$ had an increased risk for more frequent use of illicit drugs. Also for French-speaking workers (OR 2.4, CI 1.64 to 3.51), workers who were living alone (OR 1.8, CI 1.18 to 2.85, $\mathrm{p}=0.007)$ and those who had a lower level of education (OR 1.80 , CI 1.24 to $2.62, p=0.002$ ), this risk was increased. Of all respondents, $17.1 \%$ took prescribed psychoactive medication, that is, hypnotics $(9.3 \%)$, tranquillisers $(5.5 \%)$ and antidepressants (7.9\%). Medication use was significantly more frequent in women $(20.1 \%$ vs $13.3 \%$; $\mathrm{p}<0.001)$. There was a significant correlation between the use of NMPD $(11.3 \%$ of all respondents) and using illicit drugs more frequently $(\mathrm{p}<0.001)$. This is to be expected as the metabolism and mechanism of action for each drug will often dictate the frequency with which people go into withdrawal.

Finally, $81 \%$ of all respondents never drank at work, $16.7 \%$ monthly or less and $2.3 \%$ at least two to four times a month. Alcohol drinking at work was significantly more often present in companies with persons with a higher level of education $(29.3 \%$ vs $11.2 \% ; \mathrm{p}<0.001)$ and with workers $\leq 35$ years $(21 \%$ vs $17.8 \% ; p=0.004)$, in companies with $\geq 200$ workers $(21.8 \%$ vs $17.7 \% ; \mathrm{p}=0.001)$ and in the government and education sectors. In those sectors, $31 \%$ and $26.7 \%(\mathrm{p}<0.001)$ of all respondents had drunk alcohol at least monthly or less during the last year.

\section{Experienced job-related impact of self-reported AOD use}

In this study, $12.2 \%$ of last-year drinkers experienced consequences in their job, which they related to their self-reported alcohol consumption. For illicit drug use (cannabis and other illicit drugs) and psychoactive medication, this was $15.2 \%$ and $17.6 \%$ of respondents, respectively (table 4 ). With respect to the perception of job-related effects among colleagues, $27.8 \%$ of workers indicated that they had observed negative effects of alcohol use among their colleagues, while this was $7.2 \%$ and $10.7 \%$ for illicit drugs and psychoactive medication, respectively.

Nearly $20 \%$ of workers with an indication of problem drinking based on the AUDIT-C Score experienced job-related effects. Especially workers who were living alone $(30.3 \%$ vs $18.0 \%$, $\mathrm{p}<0.001)$, male workers $(25.2 \%$ vs $13.4 \%, \mathrm{p}<0.001)$ and workers under the age of 36 years $(25.9 \%$ vs $14.7 \%, p<0.001)$ were involved. Workers with this indication of problem drinking 
Table 2 Use of alcohol and other drugs $(n=5367)$

\begin{tabular}{|c|c|c|c|c|c|c|c|c|}
\hline $\begin{array}{l}n=5367 \text { (LY) valid } \% \text { are } \\
\text { used }\end{array}$ & Alcohol ever & $\begin{array}{l}\text { Alcohol > once a } \\
\text { week }\end{array}$ & $\begin{array}{l}\text { Psychoactive } \\
\text { medication ever }\end{array}$ & NMPD ever & Cannabis ever & $\begin{array}{l}\text { Cannabis frequent } \\
\text { use* }\end{array}$ & $\begin{array}{l}\text { Other illicit drugs } \\
\text { ever }\end{array}$ & $\begin{array}{l}\text { Other illicit drugs } \\
\text { frequent use* }\end{array}$ \\
\hline & $83.1 \%$ & $30.9 \%$ & $17.1 \%$ & $11.3 \%$ & $7.4 \%$ & $3.4 \%$ & $2.8 \%$ & $0.7 \%$ \\
\hline \multicolumn{9}{|l|}{ Language } \\
\hline $\mathrm{X}^{2}$ & $<0.001$ & $<0.001$ & ns & $<0.001$ & $<0.001$ & $<0.001$ & $<0.001$ & 0.011 \\
\hline Dutch-speaking & 85 & 32.5 & 16.6 & 10.0 & 6.9 & 2.7 & 2.8 & 0.5 \\
\hline French-speaking & 74.5 & 23.7 & 19.2 & 17.2 & 9.8 & 6.6 & 2.6 & 1.3 \\
\hline \multicolumn{9}{|l|}{ Gender } \\
\hline $\mathrm{X}^{2}$ & $<0.001$ & $<0.001$ & $<0.001$ & ns & $<0.001$ & $<0.001$ & $<0.001$ & 0.002 \\
\hline Male & 87.1 & 40.8 & 13.3 & 10.9 & 11.9 & 5.9 & 4.8 & 1.1 \\
\hline Female & 80.2 & 23.2 & 20.1 & 11.2 & 3.9 & 1.4 & 1.1 & 0.3 \\
\hline \multicolumn{9}{|l|}{ Age } \\
\hline $\mathrm{X}^{2}$ & $<0.001$ & $<0.001$ & $<0.001$ & ns & $<0.001$ & $<0.001$ & $<0.001$ & $<0.001$ \\
\hline$\leq 35$ years & 83.7 & 27.4 & 12.8 & 12.1 & 14.4 & 6.7 & 5.2 & 1.3 \\
\hline$>35$ years & 83.0 & 33.5 & 19.7 & 10.5 & 2.8 & 1.2 & 1.2 & 0.2 \\
\hline \multicolumn{9}{|l|}{ Educational level } \\
\hline $\mathrm{X}^{2}$ & $<0.001$ & $<0.001$ & ns & $<0.001$ & $<0.001$ & $<0.001$ & 0.007 & \\
\hline $\begin{array}{l}\text { Primary/secondary (lower } \\
\text { education) }\end{array}$ & 79.3 & 24.7 & 17.3 & 14.4 & 8.3 & 4.6 & 3.4 & 1.1 \\
\hline $\begin{array}{l}\text { College/university } \\
\text { (higher education) }\end{array}$ & 88.2 & 38.3 & 16.3 & 7.3 & 6.8 & 2.4 & 2.2 & 0.2 \\
\hline \multicolumn{9}{|l|}{ Family context } \\
\hline $\mathrm{X}^{2}$ & $<0.001$ & $<0.001$ & 0.023 & 0.002 & $<0.001$ & $<0.001$ & $<0.001$ & 0.046 \\
\hline Living alone & 85.9 & 38.6 & 20.5 & 12.1 & 15.8 & 7.4 & 7.4 & 1.3 \\
\hline Living with others & 83.0 & 30.2 & 16.5 & 11.1 & 6.4 & 2.9 & 2.2 & 0.6 \\
\hline \multicolumn{9}{|l|}{ Employment sector } \\
\hline $\mathrm{X}^{2}$ & $<0.001$ & 0.001 & $<0.001$ & ns & $<0.001$ & $<0.001$ & $<0.001$ & $<0.001$ \\
\hline Construction & 90.3 & 42.4 & 7.5 & 12.0 & 12.6 & 8.5 & 6.0 & 2.2 \\
\hline Services & 83.9 & 34.7 & 18.1 & 11.1 & 6.9 & 2.7 & 2.7 & 0.4 \\
\hline Healthcare & 82.3 & 21.8 & 21.5 & 12.7 & 4.6 & 1.6 & 1.3 & 0.2 \\
\hline Distributive trade & 81.1 & 28.4 & 16.1 & 10.9 & 8.1 & 5.3 & 1.7 & 1.0 \\
\hline $\begin{array}{l}\text { Accommodation and food } \\
\text { service }\end{array}$ & 81.9 & 31.3 & 20.9 & 15.7 & 20.4 & 13.4 & 5.8 & 2.9 \\
\hline Manufacturing & 86.3 & 37.7 & 16.2 & 7.7 & 13.0 & 5.2 & 4.0 & 1.2 \\
\hline Education & 81.4 & 33.5 & 15.4 & 8.5 & 3.6 & 0.8 & 2.5 & 0.0 \\
\hline Government & 88.6 & 38.8 & 17.0 & 7.7 & 4.7 & 1.7 & 1.1 & 0.2 \\
\hline Transport and storage & 82.4 & 36.9 & 15.3 & 12.8 & 7.8 & 3.7 & 1.9 & 0.5 \\
\hline Other & 81.1 & 27.9 & 12.9 & 11.7 & 8.5 & 3.3 & 3.9 & 0.9 \\
\hline
\end{tabular}

Psychoactive medication: hypnotics, tranquillisers and antidepressants.

*, Defined as $>$ once a month within the last year.

$\chi^{2}$, Pearson $\chi^{2}$ test.

ever, at least once; LY, last year (past 12 months); NMPD, non-medical use of prescription drugs.

were more likely to experience job-related effects (OR 3.6, CI 2.86 to 4.60 ). This ratio decreased to 3.2 (CI 2.52 to 4.11 , $\mathrm{p}<0.001$ ), controlling for sociodemographic and organisational variables (table 5).

Also respondents who used illicit drugs more frequently (> once a month) had an increased risk for job-related effects due to this illicit drug use (OR 5.8, CI 2.87 to $11.84, \mathrm{p}<0.001)$. This risk level remained equal (OR 5.8, CI 2.78 to $12.22, \mathrm{p}<0.001$ ) after controlling for sociodemographic and organisational variables (all ns).

\section{Well-being and AOD use}

The majority of workers in this study was satisfied with their job (79.6\%, agreed/strongly agreed), received appreciation from their supervisor $(70.3 \%)$ and felt that their job had enough variation (79.9\%). However, $50.7 \%$ of the respondents mentioned having to work under time pressure. For only $10.9 \%$ of all workers was well-being at work explicitly positive. Respondents with a lower level of well-being drank significantly more frequently (more than once a week, $\mathrm{p}<0.001$ ).
Workers with a lower level of well-being had an increased risk for problem drinking based on the AUDIT-C Score (OR 1.4, CI 1.13 to $1.73, \mathrm{p}=0.002)$. After controlling for demographic and organisational characteristics the OR was 1.3 (sector not significant).

We did not find significant associations between the level of well-being and different types of illicit drugs use, including the use of NMPD, nor with job-related effects. We found an association between the level of well-being and the use psychoactive medication ever. Workers who had a lower level of well-being were more likely to have ever used psychoactive medication. In addition, having a low level of well-being increased the risk of job-related effects due to psychoactive medication (OR 2.3, CI 1.10 to $4.91 ; \mathrm{p}=0.035)$.

\section{DISCUSSION}

This study reports findings on the associations between self-reported AOD use and job-related effects, experienced by workers, as well as on the well-being of workers. Alcohol was the most prevalent drug used among Belgian workers. A robust finding 
Table 3 Problem drinking based on AUDIT-C Score

\begin{tabular}{|c|c|c|c|c|c|}
\hline $\begin{array}{l}n=4197(\text { LY) } \\
\text { valid \% are used }\end{array}$ & $\begin{array}{l}\text { Indication of problem } \\
\text { drinking based on } \\
\text { AUDIT-C }\end{array}$ & $\begin{array}{l}\text { Frequency min two to } \\
\text { three times/week }\end{array}$ & $\begin{array}{l}\text { SU alcohol } \\
\text { three or four (on a typical } \\
\text { day when drinking) }\end{array}$ & $\begin{array}{l}\text { SU alcohol } \\
\text { five or more * (on } \\
\text { a typical day when } \\
\text { drinking) }\end{array}$ & $\begin{array}{l}\text { Binge drinking at least } \\
\text { once a week }\end{array}$ \\
\hline & $39.1 \%$ & $37.1 \%$ & $24 \%$ & $11.4 \%$ & $8.6 \%$ \\
\hline \multicolumn{6}{|l|}{ Language } \\
\hline $\mathrm{X}^{2}$ & ns & $<0.001$ & ns & ns & ns \\
\hline Dutch-speaking & 39.0 & 38.2 & 23.6 & 11.1 & 7.8 \\
\hline French-speaking & 39.6 & 31.8 & 25.8 & 13.2 & 12.8 \\
\hline \multicolumn{6}{|l|}{ Gender } \\
\hline$X^{2}$ & $<0.001$ & $<0.001$ & $<0.001$ & $<0.001$ & $<0.001$ \\
\hline Male & 45.1 & 46.8 & 28.3 & 18.8 & 14.4 \\
\hline Female & 33.7 & 28.9 & 20.2 & 4.8 & 3.4 \\
\hline \multicolumn{6}{|l|}{ Age } \\
\hline$X^{2}$ & $<0.001$ & $<0.001$ & $<0.001$ & $<0.001$ & $<0.001$ \\
\hline$\leq 35$ years & 43.2 & 32.7 & 24.9 & 15.2 & 9.5 \\
\hline$>35$ years & 36.2 & 40.3 & 23.4 & 8.8 & 7.9 \\
\hline \multicolumn{6}{|l|}{ Educational level } \\
\hline $\mathrm{X}^{2}$ & 0.012 & $<0.001$ & $<0.001$ & $<0.001$ & $<0.001$ \\
\hline $\begin{array}{l}\text { Primary/secondary (lower } \\
\text { education) }\end{array}$ & 36.9 & 31.2 & 24.7 & 15.0 & 10.2 \\
\hline $\begin{array}{l}\text { College/university (higher } \\
\text { education) }\end{array}$ & 41.3 & 43.4 & 23.5 & 8.0 & 6.9 \\
\hline \multicolumn{6}{|l|}{ Family context } \\
\hline$X^{2}$ & $<0.001$ & $<0.001$ & $<0.001$ & $<0.001$ & $<0.001$ \\
\hline Living alone & 52.6 & 45.0 & 28.6 & 17.3 & 16.0 \\
\hline Living with others & 37.4 & 36.3 & 23.4 & 10.6 & 7.6 \\
\hline \multicolumn{6}{|l|}{ Employment sector } \\
\hline$X^{2}$ & $<0.001$ & $<0.001$ & $<0.001$ & $<0.001$ & $<0.001$ \\
\hline Construction & 51.6 & 47.0 & 27.7 & 24.1 & 21.6 \\
\hline Services & 41.3 & 41.3 & 28.7 & 9.9 & 7.1 \\
\hline Healthcare & 30.2 & 26.6 & 19.6 & 5.8 & 4.2 \\
\hline Distributive trade & 41.7 & 35.0 & 26.0 & 13.9 & 9.4 \\
\hline $\begin{array}{l}\text { Accommodation and food } \\
\text { service }\end{array}$ & 49.1 & 38.1 & 24.1 & 17.9 & 11.4 \\
\hline Manufacturing & 46.7 & 43.7 & 28.8 & 18.2 & 10.8 \\
\hline Education & 39.7 & 41.1 & 22.5 & 6.2 & 5.2 \\
\hline Government & 37.5 & 43.8 & 20.7 & 10.4 & 8.0 \\
\hline Transport and storage & 38.5 & 44.8 & 23.1 & 16.2 & 13.9 \\
\hline Other & 39.6 & 34.5 & 24.8 & 12.5 & 9.4 \\
\hline
\end{tabular}

Binge drinking: more than six standard units of alcohol per occasion; scores: $\geq$ weekly.

Score with indication problem drinking (men $\geq 5$; women $\geq 4$ ).

$\chi^{2}$, Pearson's $\chi^{2}$ test.

${ }^{*}$, Sum of ' 5 or 6', '7 to 9 ' and ' $\geq 10$ '.

AUDIT-C, Alcohol Use Disorders Identification Test-Consumption; LY, last year (past 12 months); SU, standard unit.

was that mainly male workers consumed alcohol and this was the case for all types of consumption patterns. Workers with an indication of problem use (for alcohol, based on AUDIT-C Score; for illicit drugs, use more than once a month) had higher risks for job-related effects. On the other hand, this risk decreased when they had a high level of well-being, although only in case of psychoactive medication. A substantial part (11.3\%) of the respondents in our study took prescribed drugs for non-medical reasons. Most workers did not use alcohol in the workplace.

\section{Prevalence of AOD use}

These results are in line with international research, in which men were consistently shown to exceed women in typical drinking frequencies, quantities and rates of heavy drinking episodes. ${ }^{30} 31$
Gender differences in drinking behaviour have been linked with biological (eg, suffering with alcohol-related physical illnesses at lower level of alcohol exposure) and psychosocial consequences (eg, women perceive greater social consequences) of alcohol drinking for women, which may be protective factors against alcohol use disorders. ${ }^{31}$ Internationally, alcohol use seems to be particularly prevalent among workers in male-dominated industries and in some of the sectors more affected by the problem (eg, drivers, construction workers, waiters and unskilled/manual workers). ${ }^{7} 1032$ However, high-risk drinking is also associated with managers. ${ }^{32}$

In most workplaces, alcohol consumption is only permitted on special occasions. ${ }^{67}$ In general, alcohol consumption at work is influenced by a permissive alcohol climate, in particular by 


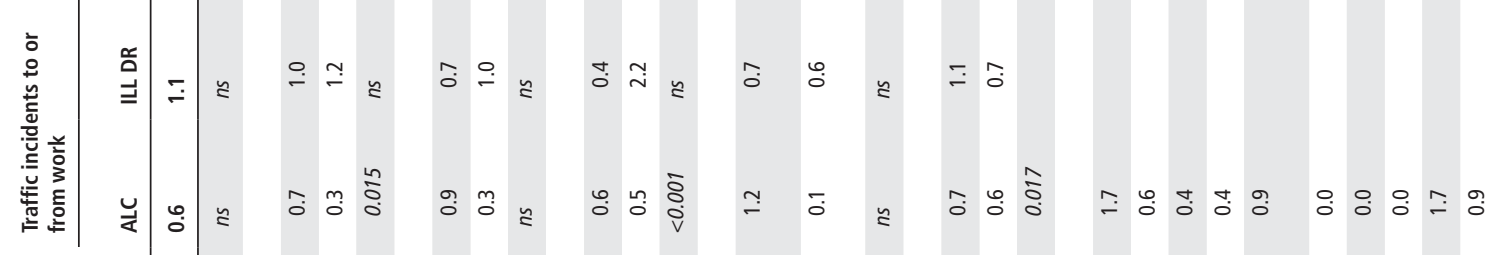

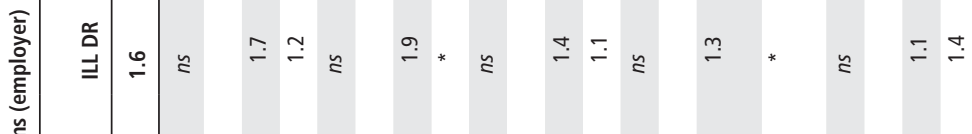

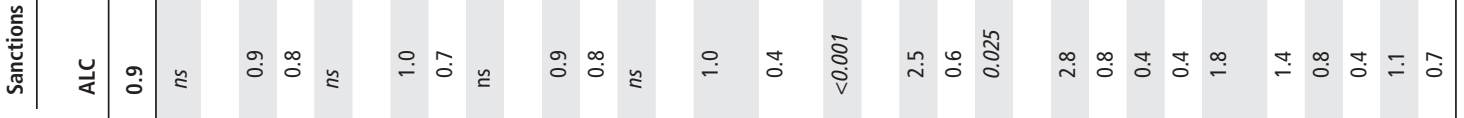

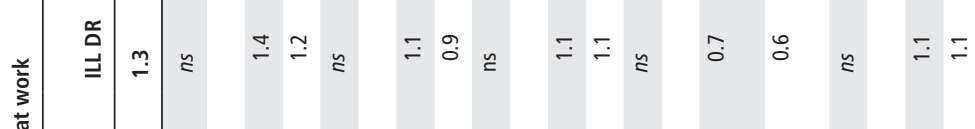

旁

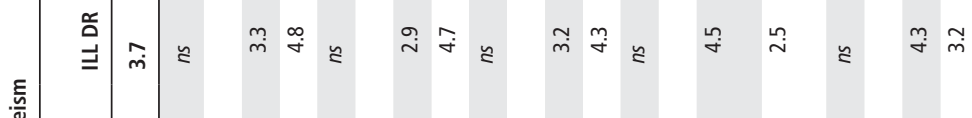

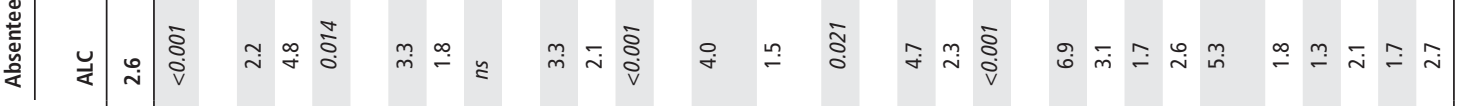

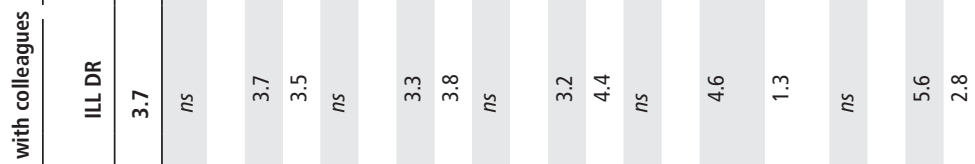

竧

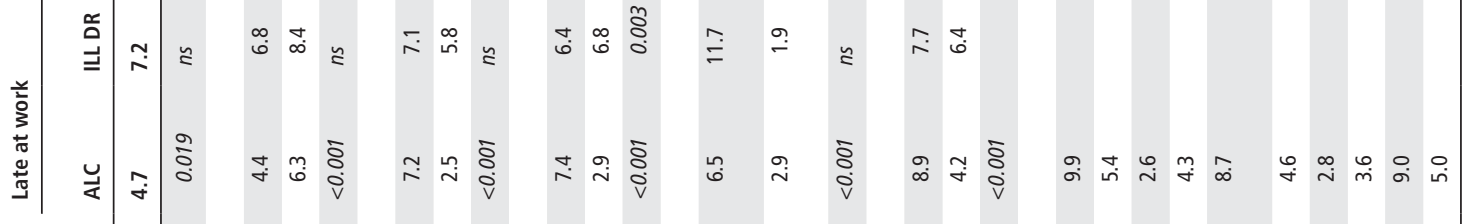

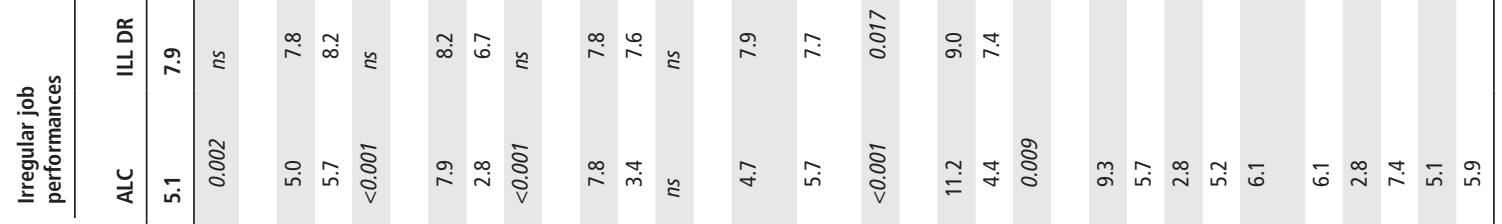

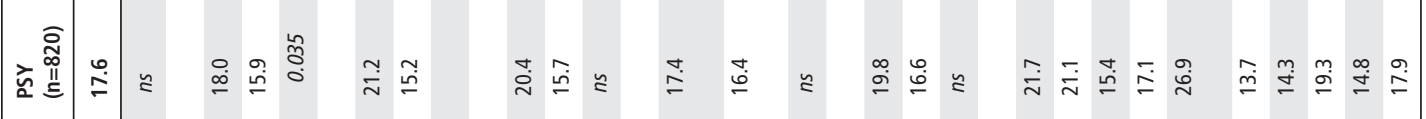
节

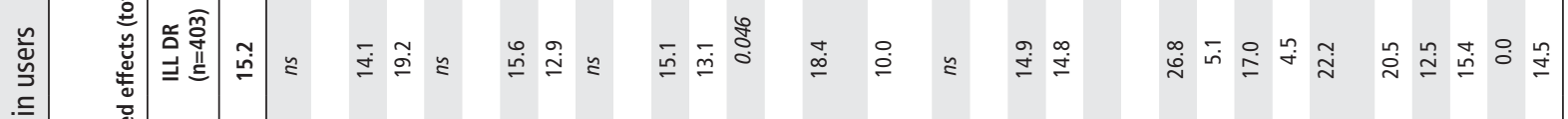

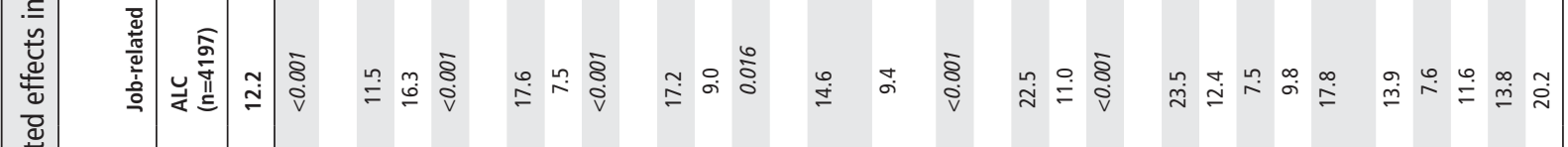

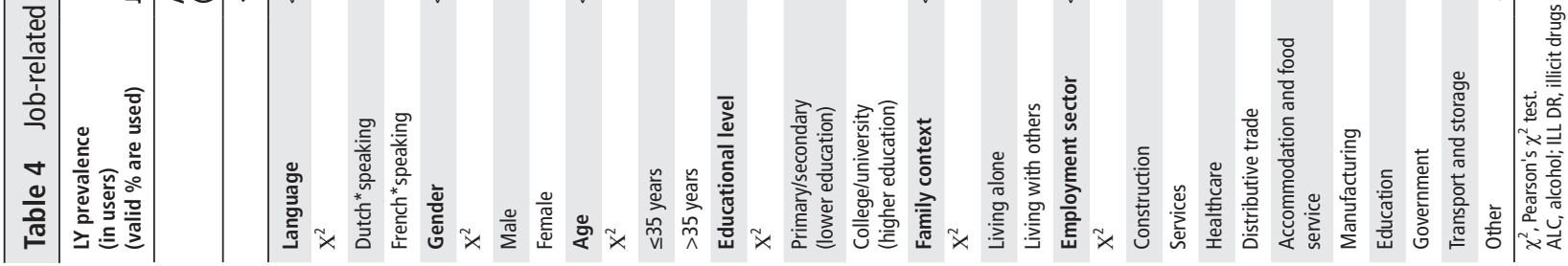


Table 5 Association between Alcohol Use Disorders Identification Test-Consumption (AUDIT-C) Score and experienced job-related effects, adjusted for language (ns), gender, age, family context, level of education and sector (ns)

$$
\text { OR }(95 \% \mathrm{Cl}) \quad \text { P values }
$$

Outcome variable:

AUDIT-C Score and experienced job-related effects

\begin{tabular}{lll}
\hline Crude model & $3.6(2.86$ to 4.60$)$ & $<0.001$ \\
\hline $\begin{array}{ll}\text { Adjusted model } \\
\text { * }\end{array}$ & $3.2(2.52$ to 4.11$)$ & $<0.001$ \\
\hline Langusted for & & ns \\
Gender & $2.2(1.76$ to 2.90$)$ & $<0.001$ \\
\hline Age & $2.2(1.30$ to 2.56$)$ & $<0.001$ \\
\hline Family context & $1.8(1.30$ to 2.40$)$ & $<0.001$ \\
\hline Level of education & $1.5(1.12$ to 1.92$)$ & $<0.001$ \\
\hline Sector & & ns \\
\hline
\end{tabular}

drinking norms. ${ }^{33}$ In Belgium, following the Collective Labour Agreement $n^{\circ} 100,{ }^{34}$ many private companies have introduced rules on the availability and consumption of AOD in the workplace. Due to the deleterious effects on job behaviour of AOD use outside the workplace, CLA also focuses on prevention and early detection of job-related problems due to AOD use. ${ }^{34}$ In contrast, there is currently no similar legislation for public companies, nor for people working in education, which might be an explanation for the high ranking of the government and education sectors. ${ }^{34}$

The use of NMPD might be related to the increasing number of people that are reported to use cognition-enhancing drugs. ${ }^{35}$ By using these drugs, workers want to maintain or improve work performance level of attention, memory and so on, and try to cope with daily stress and demands of a changing work environment. ${ }^{35}$ More research is needed to understand the underlying motives of NMPD use.

\section{Job-related effects due to AOD use}

Our results, especially of alcohol use on (self-reported) work performance, are consistent with similar research internationally. ${ }^{891436}$ In literature, job-related consumption, mainly of alcohol, is associated with negative impacts on individuals and organisations, for example, more instances of sick leave/ short-term absenteeism, reduced performance, labour conflicts, more work injuries, mobility problems, image problems, and damage to equipment or products. ${ }^{7123637}$ Binge drinking is more strongly associated with activity impairments than annual drinking frequency. ${ }^{12}$ In addition, workplace drinking and coming to work with a hangover predict work-related problems. ${ }^{18}$ Some studies show a positive relationship between AOD use and labour conflicts and aggression at work with colleagues as well as with supervisory staff, probably as a result of inappropriate behaviour at work. ${ }^{36}$

However, specific studies on other drug use and job-related effects are rare. Pidd et al refer to the relatively low illicit drug use prevalence rates among workforces internationally, stating the prevalence of drug-related workplace accidents and injuries is also likely to be low. ${ }^{38}$ They suggested that future research might need to consider other outcome measures related to the broader workplace culture and absenteeism rates. In addition, other productivity and worker well-being indicators may be needed. ${ }^{38}$ In international studies, the relation of work stressors with a higher degree of AOD use has already been established. ${ }^{39}$
Analysis of the work environment as a potential cause of worker substance use shows the importance of measures that assess AOD use in terms of their relation to the workday. ${ }^{13}$

\section{An integrated alcohol and drug policy}

Internationally, a multicomponent policy is considered to be an asset in the face of AOD-related problems on the work floor. ${ }^{2140}$ It includes rules on the availability and consumption of AOD in the workplace; intervention procedures in case of malfunctioning; assessment and referral of workers with an alcohol or drug problem; and information and education. ${ }^{40}$ Having a job seems to be a motivating and protective factor to tackle alcohol or drug problems, and to prevent relapse. ${ }^{22}$ Therefore, a prevention policy might be applied to both targeted workers (eg, safety functions) and all workers (universal prevention). ${ }^{40}$ Among others, Ames et al underlined the importance of an environmental approach, in which both individual and organisational factors, as well as the responsibility of workers and employers are taken into account. ${ }^{14181932}$

\section{Limitations}

Despite the high response rate of our study, our sample refers to a selected group of workers involved in periodic medical examinations by an occupational physician on an annual basis (about $50 \%$ of the workers). Further, we could not verify the size and types of the job-related consequences since they were investigated through self-reports. Self-reports result in an underestimation of real AOD use. However, workers were literally asked whether they attributed the job-related effects they experienced to their own AOD use. In addition, the operationalisation of well-being did not include job stress, since this is not the same as time pressure. Finally, due to its cross-sectional design, it is not possible to draw causal associations.

\section{CONCLUSIONS}

Based on self-reported data, we were able to link AOD use with job-related effects experienced by workers. Further, here we collected specific data on both illicit drugs and psychoactive medication in relation to job effects and included non-medical use of prescribed drugs. Finally, we believe that an environment perceived as safe and an old-school questionnaire on paper strongly contributed to the high response rate.

Acknowledgements The authors thank Dr Chris Verbeek (IDEWE), and the Research and Development Department of CESI for their highly appreciated collaboration in organising this study.

Contributors $\mathrm{M}-\mathrm{CL}$, LV and LG participated in the design of the study and made the questionnaire. LV constructed the database for analysis. LV and M-CL performed the statistical analysis. All authors contributed to the interpretation of the results. $\mathrm{M}-\mathrm{CL}$ wrote the first draft of the manuscript. All authors read and approved the final version before submission.

Funding This research was financed by the Belgian Science Policy Office; the Federal Public Service Health, Food Chain Safety and Environment and the Federal Public Service Employment, Labour and Social Dialogue (Contract DR/00/60).

Competing interests None declared.

Patient consent for publication Not required.

Ethics approval Social and Societal Ethics Committee (SMEC) of KU Leuven, University of Leuven (G-2015 09 316; 24 September 2015).

Provenance and peer review Not commissioned; externally peer reviewed.

Open access This is an open access article distributed in accordance with the Creative Commons Attribution Non Commercial (CC BY-NC 4.0) license, which permits others to distribute, remix, adapt, build upon this work non-commercially, and license their derivative works on different terms, provided the original work is 
properly cited, appropriate credit is given, any changes made indicated, and the use is non-commercial. See: http://creativecommons.org/licenses/by-nc/4.0/.

\section{REFERENCES}

1 WHO, Management of Substance Abuse Unit. Global status report on alcohol and health 2018. Geneva: World Health Organization, 2018:450.

2 Lim SS, Vos T, Flaxman AD, et al. A comparative risk assessment of burden of disease and injury attributable to 67 risk factors and risk factor clusters in 21 regions, 19902010: a systematic analysis for the Global Burden of Disease Study 2010. Lancet 2012:380:2224-60.

3 EMCDDA, European Monitoring Centre for Drugs and Drug Addiction. 2017. European Drug Report 2017: Trends and Developments. Luxembourg: Publications Office of the European Union: 96.

4 International Narcotics Control Board. 2014. Psychotropic Substances 2013. Statistics for 2012; Assessments of AnnualMedical and Scientific Requirements for Substances in Schedules II, III and IV of the Convention on Psychotropic Substances of 1971. New York, USA: United Nations: 412. 978-92-1-048155-7.

5 Novak SP, Håkansson A, Martinez-Raga J, et al. Nonmedical use of prescription drugs in the European Union. BMC Psychiatry 2016;16:274.

6 Frone MR. Alcohol and Illicit Drugs in the Workforce and Workplace: American Psychological Association, 2013.

7 Corral A, Duran J, Isusi I. Use of alcohol and drugs at the workplace. Dublin, Ireland: European Foundation for the Improvement of Living and Working Conditions, 2012

8 Salonsalmi A, Rahkonen O, Lahelma E, et al. The association between alcohol drinking and self-reported mental and physical functioning: a prospective cohort study among City of Helsinki employees. BMJ Open 2017;7:e014368.

9 Vahtera J, Poikolainen K, Kivimäki M, et al. Alcohol intake and sickness absence: a curvilinear relation. Am J Epidemiol 2002;156:969-76.

10 Roche AM, Lee NK, Battams S, et al. Alcohol use among workers in male-dominated industries: A systematic review of risk factors. Safety Science 2015;78:124-41.

11 Watt K, Purdie DM, Roche AM, et al. Risk of injury from acute alcohol consumption and the influence of confounders. Addiction 2004;99:1262-73.

12 Aas RW, Haveraaen L, Sagvaag $H$, et al. The influence of alcohol consumption on sickness presenteeism and impaired daily activities. The WIRUS screening study. PLoS One 2017;12:e0186503.

13 Frone MR. Are work stressors related to employee substance use? The importance of temporal context assessments of alcohol and illicit drug use. J App/ Psychol 2008:93:199-206.

14 Bacharach S, Bamberger P, Sonnenstuhl W. Driven to Drink: Managerial Control, Work Related Rick Factors, and Employee Problem Drinking. The Academy of Management Journal 2002;45:637-58

15 Sonnenstuhl WJ, Trice HM. The workplace as locale for risks and interventions in alcohol abuse. Roman PM, Alcohol: The development of sociological perspectives on use and abuse. New Brunswick: Rutgers Center of Alcohol Studies, 1991:255-88.

16 Danna K, Griffin RW. Health and Well-Being in the Workplace: A Review and Synthesis of the Literature. Journal of Management 1999;25:357-84.

17 Nielsen MB, Gjerstad J, Frone M. Alcohol use among Norwegian workers: associations with health and well-being. Occup Med 2018;68:96-8.

18 Ames GM, Bennett JB. Prevention interventions of alcohol problems in the workplace. A review and Guiding Framework. Alcohol Res Health 2011;34:175-87.

19 Harvey SB, Joyce S, Tan L, et al. 2014. Developing a mentally healthy workplace: A review of the literature. A report for the National Mental Health Commission and the Mentally Healthy Workplace Alliance: 73. https://apo.org.au/node/57690.
20 Schulte B, O'Donnell AJ, Kastner $S$, et al. Alcohol screening and brief intervention in workplace settings and social services: a comparison of literature. Front Psychiatry 2014;5:131.

21 Liira H, Knight AP, Sim MGB, et al. Workplace interventions for preventing job loss and other work related outcomes in workers with alcohol misuse. Cochrane Database of Systematic Reviews 2016;34:12.

22 McHugo GJ, Drake RE, Xie H, et al. A 10-year study of steady employment and non-vocational outcomes among people with serious mental illness and co-occurring substance use disorders. Schizophr Res 2012;138:233-9.

23 Kaarne T, Aalto M, Kuokkanen M, et al. AUDIT-C, AUDIT-3 and AUDIT-QF in screening risky drinking among Finnish occupational health-care patients. Drug Alcohol Rev 2010;29:563-7.

24 Saunders JB, Aasland OG, Babor TF, et al. Development of the Alcohol Use Disorders Identification Test (AUDIT): WHO Collaborative Project on Early Detection of Persons with Harmful Alcohol Consumption--II. Addiction 1993:88:791-804.

25 Smith PC, Schmidt SM, Allensworth-Davies D, et al. A single-question screening test for drug use in primary care. Arch Intern Med 2010;170:1155-60.

26 Vandenbroeck S, Van Gerven E, De Witte H, et al. Burnout in Belgian physicians and nurses. Occup Med 2017:67:546-54.

27 Demerouti E, Bakker AB, Nachreiner F, et al. The job demands-resources model of burnout. J Appl Psychol 2001;86:499-512.

28 Kessler RC, Barber C, Beck A, et al. The World Health Organization Health and Work Performance Questionnaire (HPQ). J Occup Environ Med 2003;45:156-74.

29 Belgium SDGS-S. 2018. Belgium in figures. Survey Labor Force. Calculations FPS ELSD Federal Public Service Employment, Labour and Social Dialogue.

30 Wilsnack RW, Vogeltanz ND, Wilsnack SC, et al. Gender differences in alcohol consumption and adverse drinking consequences: cross-cultural patterns. Addiction 2000:95:251-65

31 Erol A, Karpyak VM. Sex and gender-related differences in alcohol use and its consequences: Contemporary knowledge and future research considerations. Drug Alcohol Depend 2015;156:1-13

32 Marchand A. Alcohol use and misuse: what are the contributions of occupation and work organization conditions? BMC Public Health 2008;8:333.

33 Frone MR. Does a permissive workplace substance use climate affect employees who do not use alcohol and drugs at work? A U.S. national study. Psychol Addict Behav 2009;23:386-90

34 Staatsblad B. 28 JUNI 2009. Koninklijk besluit waarbij algemeen verbindend wordt verklaard de collectieve arbeidsovereenkomst nr. 100 van 1 april 2009, gesloten in de Nationale Arbeidsraad, betreffende een preventief alcohol- en drugbeleid in de onderneming. 28 JUIN 2009. - Arrêté royal rendant obligatoire la convention collective de travail $n^{\circ} 100$ du 1er avril 2009, conclue au sein du Conseil national du Travail, concernant la mise en oeuvre d'une politique préventive en matière d'alcool et de drogues dans l'entreprise Justitie BS-FO, Justice MB-SPF (eds.). Brussel, 2009.

35 Brühl AB, Sahakian BJ. Drugs, games, and devices for enhancing cognition: implications for work and society. Ann N Y Acad Sci 2016;1369:195-217.

36 McFarlin SK, Fals-Stewart W. Workplace absenteeism and alcohol use: a sequential analysis. Psychol Addict Behav 2002;16:17-21.

37 Mangione TW, Howland J, Amick B, et al. Employee drinking practices and work performance. J Stud A/cohol 1999;60:261-70.

38 Pidd K, Roche AM. How effective is drug testing as a workplace safety strategy? A systematic review of the evidence. Accid Anal Prev 2014;71:154-65.

39 Trinkoff AM, Zhou Q, Storr CL, et al. Workplace access, negative proscriptions, job strain, and substance use in registered nurses. Nurs Res 2000;49:83-90.

40 Webb G, Shakeshaft A, Sanson-Fisher R, et al. A systematic review of work-place interventions for alcohol-related problems. Addiction 2009:104:365-77. 